\title{
Table of ESMA soft law acts and other relevant documents
}

This table is not exhaustive, as it contains in particular those acts that are mentioned throughout the book.

\section{ESMA's Draft Technical and Implementing Technical Standards}

ESMA, Draft RTS on the content and format of ratings data periodic reporting to be requested from credit ratings agencies for the purpose of on-going supervision by ESMA (2011) ESMA/2011/464

91

ESMA, Discussion paper on Key concepts of the Alternative Investment Fund Managers Directive and types of AIFM (2012) ESMA/2012/117

158

ESMA, Consultation paper on Draft regulatory technical standards on types of AIFMs (2012) ESMA/2012/844

156,158

ESMA, Final report on Draft regulatory technical standards on types of AIFMs (2013) ESMA/2013/413

$156,157,159$

ESMA, Consultation paper on the Guidelines on reporting obligations under Article 3 and Article 24 of the AIFMD (2013) ESMA/2013/592

166

ESMA, Opinion on Draft regulatory technical standards on types of AIFMs under Article 4(4) of Directive 2011/61/EU (2013) 2013/ESMA/1119

159

ESMA, Annex III to the Final Report on draft Technical Standards under the Regulation No 909/2014 of the European Parliament and of the Council of 23 July 2014 on improving securities settlement in the European Union and on central securities depositories and amending Directives 98/26/EC and 2014/65/EU and Regulation (EU) No 236/2012 (2015) ESMA/2015/1457/Annex III

89,91

ESMA, Opinion on Draft Implementing Technical Standards on main indices and recognised exchanges under the Capital Requirements Regulation (2016) ESMA/2016/163

135,160

ESMA, Discussion Paper on Draft RTS and ITS under SFTR (2016) ESMA/2016/356

163

ESMA, Opinion on Draft Regulatory Technical Standards on methodology for calculation and the application of position limits for commodity derivatives traded on trading venues and economically equivalent OTC contracts (2016) ESMA/2016/668

ESMA, Final Report on Draft regulatory technical standards on indirect clearing arrangements under EMIR and MiFIR (2016) ESMA/2016/725

ESMA, Consultation Paper on the Guidelines on participant default rules and procedures under CSDR (2016) ESMA/2016/732 
ESMA, Opinion on Draft Implementing Technical Standards on the technical means for appropriate public disclosure of inside information and for delaying the public disclosure of inside information (2016) ESMA/2016/982

107,165

ESMA, Consultation Paper on Draft Regulatory Technical Standards under the Benchmarks Regulation (2020) ESMA70-156-1464

163,164

ESMA, Final Report on Draft technical standards on the provision of investment services and activities in the Union by third-country firms under MiFID II and MiFIR (2020) ESMA35-43-2424

ESAs, Joint ESA consultation on ESG disclosures (2020) JC 202016

\section{ESMA's Guidelines and Recommendations}

ESMA, Guidelines to competent authorities and UCITS management companies on risk measurement and the calculation of global exposure for certain types of structured UCITS (2011) ESMA/2011/112

ESMA, Guidelines on the application of the endorsement regime under Article 4(3) of the Credit Rating Agencies Regulation No 1060/2009 (2011) ESMA/2011/139 169

ESMA, Guidelines on the Exemption for market making activities and primary market operations under Regulation (EU) 236/2012 of the European Parliament and the Council on short selling and certain aspects of Credit Default Swaps (2013) ESMA/2013/74

$185,193,219,226$

ESMA, Guidelines on Remuneration Policies and Practices MiFID (2013) ESMA/2013/606

186

ESMA, Guidelines and Recommendations regarding written agreements between members of CCP colleges (2013) ESMA/2013/661

93, 128

ESMA, Guidelines and Recommendations on the Scope of the CRA Regulation (2013) ESMA/2013/720

ESMA, Guidelines on reporting obligations under Articles 3(3)(d) and 24(1), (2) and (4) of the AIFMD (2014) ESMA/2014/869

166,208

ESMA, Guidelines on ETFs and other UCITS issues (2014) ESMA/2014/937 185

ESMA, Guidelines on periodic information to be submitted to ESMA by Credit Rating Agencies (2015) ESMA/2015/609

ESMA, Guidelines on the application of the definitions in Sections C6 and C7 of Annex I of Directive 2004/39/EC (2015) ESMA/2015/675

93, 94

ESMA, Guidelines on Alternative Performance Measures (2015) ESMA/2015/1057

ESMA, Guidelines on sound remuneration policies under the UCITS Directive and AIFMD (2016) ESMA/2016/411

168

ESMA, Guidelines on Cooperation between authorities under Articles 17 and 23 of Regulation (EU) No 909/2014 (2017) ESMA70-151-435

ESMA, Guidelines on the validation and review of Credit Rating Agencies' methodologies (2017) ESMA/2016/1575

ESMA, Guidelines on stress tests scenarios under Article 28 of the MMF Regulation (2018) ESMA34-49-115

ESMA, Guidelines on MiFID II product governance requirements (2018) ESMA35-43-620 


\section{ESMA’s Guidelines Compliance Tables}

ESMA, Guidelines compliance table on the Guidelines on the Exemption for market making activities and primary market operations under Regulation (EU) 236/2012 of the European Parliament and the Council on short selling and certain aspects of Credit Default Swaps (2013) ESMA/2013/765

193,232

ESMA, Guidelines compliance table on the Guidelines on Alternative Performance Measures (2015) ESMA-32-67-184

ESMA, Guidelines compliance table on Guidelines on the calibration of circuit breakers and publication of trading halts under MiFID II (2017) ESMA70-156-177 225

ESMA, Guidelines compliance table on the Guidelines for the assessment of knowledge and competence (2020) ESMA35-43-2183

169

ESMA, Guidelines compliance table on the Guidelines on the Exemption for market making activities and primary market operations under Regulation (EU) 236/2012 of the European Parliament and the Council on short selling and certain aspects of Credit Default Swaps (2021) ESMA70-21038340-46

194,226

\section{ESMA's Non-binding Instruments}

ESMA, Opinion on the composition of CCP colleges under EMIR (2015) ESMA/2015/838

ESMA, Technical Advice under the CSD Regulation (2015) ESMA/2015/1219 169

ESMA, Questions and Answers on the Application of the UCITS Directive (2016) 2016/ESMA/181

ESMA, Questions and Answers on the Market Abuse Regulation (2016) ESMA/2016/1129

ESMA, Questions and Answers on the Application of the AIFMD (2017) ESMA34-32-352

ESMA, Questions and Answers on the Guidelines on Alternative Performance Measures (2017) ESMA32-51-370

ESMA, Questions and Answers on the Application of the UCITS Directive (2017) ESMA34-43-392

ESMA, MiFID II Supervisory briefing on Appropriateness and Execution-only (2019) ESMA35-36-1640

ESMA, Public Statement: Actions to mitigate the impact of Covid-19 on the deadlines for the publication of periodic reports by fund managers' (2020) ESMA34-45-896 $\mathbf{8 5}$

ESMA, Opinion on appropriate action in respect of the new disclosure requirements in Regulation (EU) 2016/1011 of the European Parliament and of the Council relating to the sustainability-related disclosures for benchmarks (2020) ESMA41-137-1299 81

\section{Summary of Conclusions of ESMA's Board of Supervisors}

ESMA, Board of Supervisors, Summary of Conclusions of 4 July 2013 (ESMA/2013/ $\mathrm{BS} / 125)$

194, 211, 240

ESMA, Board of Supervisors, Summary of Conclusions of 24 September 2013 (ESMA/2013/BS/155)

ESMA Board of Supervisors, Summary of Conclusions of 25 September 2014 (ESMA/2014/BS/159) 
ESMA, Board of Supervisors, Summary of Conclusions of 6-7 November 2014 (ESMA/BS/201)

ESMA, Board of Supervisors, Summary of Conclusions of 21 November 2014 (ESMA/ $\mathrm{BS} / 202)$

$101,107,109$

ESMA, Board of Supervisors, Summary of Conclusions of 7 May 2015 (ESMA/ $\mathrm{BS} / 90 \mathrm{rev})$

106

ESMA, Board of Supervisors, Summary of Conclusions of 24 and 25 September 2015 (ESMA/BS/140)

$67,119,177,221$

ESMA, Board of Supervisors, Summary of Conclusions of 10 December 2015 (ESMA/2016/BS/2rev1)

ESMA, Board of Supervisors, Summary of Conclusions of 27 January 2016 (ESMA/2016/BS/61)

ESMA Board of Supervisors, Summary of Conclusions of 25 May 2016 (ESMA/2016/ BS/151rev1)

ESMA, Board of Supervisors, Summary of Conclusions of 14 December 2016 (ESMA22-247440098-55) 99

ESMA, Board of Supervisors, Summary of Conclusions of 26 January 2017 (ESMA22-247440098-103) 221

ESMA, Board of Supervisors, Summary of Conclusions of 30 January 2019 (ESMA22-106-1676) 150

ESMA, Board of Supervisors, Summary of Conclusions of 11 July 2019 (ESMA22-106-1895)

\section{Decisions of ESMA's Management Board}

ESMA, Management Board, Decision, Access to documents (2011) ESMA/2011/ $\mathrm{MB} / 69$

ESMA, Management Board, Decision on Adopting Rules of Procedure on Professional Secrecy for Non-Staff, and repealing Management Board Decision on Professional Secrecy of 11 January 2011 (2017) ESMA40-1432018523-304

153

ESMA, Management Board, Decision, Rules of procedure (2020) ESMA22-328-275 153

\section{ESMA Peer Reviews}

ESMA, Peer Review Report on MiFID Conduct of Business, fair, clear and not misleading information (2014) ESMA/2014/1485

ESMA, Peer Review Report on Compliance with SSR as regards Market Making activities (2016) ESMA/2015/1791

231, 233

ESMA, Peer Review under EMIR Art. 21 Supervisory activities on CCPs' Margin and Collateral requirements (2016) ESMA/2016/1683

ESMA, Peer Review Report on the Guidelines on enforcement of financial information (2017) ESMA42-111-4138

ESMA, Follow-up Report to the Peer Review on MiFID Conduct of Business rules relating to fair, clear and not misleading information (2017) ESMA42-113-627 221

ESMA, Follow-up Report to the Peer Review on Best Execution (2017) ESMA42-1643088512-2962

ESMA, Peer Review Report on the Guidelines on ETFs and other UCITS issues (2018) ESMA42-111-4479 


\section{ESMA Rules of Procedure}

ESMA, Procedure on publication of ESMA staff meetings with stakeholders (2016) ESMA/2016/1525

ESMA, Methodology for Mandatory Peer Reviews in relation to CCPs' authorisation and supervision under EMIR (2017) ESMA71-1154262120-155

ESMA, Decision of the Board of Supervisors Rules of procedure (2020) ESMA22-328-266

ESMA, 'Decision of the Board of Supervisors Adopting a Policy on Independence and Decision-Making Processes for avoiding Conflicts of Interest (Conflict of Interest Policy) for Non-Staff' (2020) ESMA-22-328-402

ESMA, Public Statement on Consultation Practices (2020) ESMA34-39-969 124, 127, 130

ESMA, Decision of the Securities and Markets Stakeholder Group Rules of procedure (2020) ESMA22-106-2371

ESMA, Peer Review Methodology (2020) ESMA42-111-4966229, 230, 232, 234, 235

ESMA, Decision of the Board of Supervisors Rules of procedure on breach of Union law investigations (2020) ESMA43-318-5630

236, 248

\section{Other}

ESMA, Annual Report 2015 (2016) ESMA/2016/960

ESMA, 'Call for expression of interest Consultative Working Group of ESMA's Investor Protection and Intermediaries Standing Committee (2019) ESMA35-30-658 126

ESMA, ESMA Staff Stakeholder contacts in the First Quarter 2020 (2020) ESMA20-92-154

ESMA, No Action Letter on Sustainability-Related Disclosures for Benchmarks (2020) ESMA41-137-1300

ESMA, 'Call for expressions of interest: Consultative Working Group of the ESMA Secondary Markets Standing Committee' (2020) ESMA70-154-1934 125

ESMA, Strategic Orientation 2020-2022 (2020) ESMA22-106-1942

\section{Documents of Other EU Institutions, Offices, Bodies and Agencies}

CESR, CESR's Guidelines on Risk Measurement and the Calculation of Global Exposure and Counterparty Risk for UCITS (2010) CESR/10-788

Commission, 'Communication on an Internal Market for Pension Funds' (1994) OJ 94/C 360/08

114,202

Commission, 'European Governance. A White Paper' COM(2001) 428 final 10,31, $37,50,51,52,293$

Commission, Communication, 'Towards a reinforced culture of consultation and dialogue: General principles and minimum standards for consultation of interested parties by the Commission" $\operatorname{COM}(2002) 704$ final 10

Commission, "Communication on The operating framework for the European Regulatory Agencies' COM(2002) 718 final 5

Commission, 'Proposal for an inter-institutional agreement on the operating framework for the European regulatory agencies' $\operatorname{COM}(2005) 59$ final 
Commission, 'Communication on European agencies - The way forward' COM(2008) 135 final

Commission, 'Communication on European Financial Supervision' COM(2009) 252 final

Commission, 'Proposal for a Regulation of the European Parliament and of the Council establishing a European Securities and Markets Authority' COM(2009) 503 final

Commission, Green Paper on the EU corporate governance framework, COM(2011) 164 final

Commission, Communication, 'A blueprint for a deep and genuine economic and monetary union. Launching a European Debate' COM(2012) 777 final

Commission, 'Report from the Commission to the European Parliament and the Council on the evaluation of the Regulation (EU) No 236/2012 on short selling and certain aspects of credit default swaps' $\operatorname{COM}(2013) 885$ final 193, 194, 211, 240

Commission, 'Recommendation 2014/478/EU on principles for the protection of consumers and players of online gambling services and for the prevention of minors from gambling online' (2014) OJ L214/38

202

Commission, 'Report from the Commission to the European Parliament and the Council on the operation of the European Supervisory Authorities (ESAs) and the European System of Financial Supervision (ESFS)' COM(2014) 509 final 1, 5, 200, 251, 255

Commission, Letter to ESMA regarding draft RTS on types of AIFMD, 4 July 2015 accessed 18 February 2021

Commission, 'Proposal for a Regulation of the European Parliament and of the Council amending Regulation (EU) No 182/2011 laying down the rules and general principles concerning mechanisms for control by Member States of the Commission's exercise of implementing powers' COM(2017) 85 final

206

Commission, Staff Working Document, 'Impact Assessment Accompanying the document Proposal for a Regulation amending the Regulations establishing EBA, ESMA, and EIOPA' SWD(2017) 308 final

EBA, Guidelines on the assessment of the suitability of members of the management body and key function holders (2012) EBA/GL/2012/06

254,268

EBA, Public Statement on Consultation Practices (2012) EBA BS 2012182 (II) (EBA DC 57-Annex1)

EBA, Recommendation to the Bulgarian National Bank and Bulgarian Deposit Insurance Fund on action necessary to comply with Directive 94/19/EC, EBA/ REC/2014/02, 17 Oct. 2014

EBA, Recommendation to the Maltese Financial Intelligence Analysis Unit (FIAU) on action necessary to comply with the Anti-Money Laundering and Countering Terrorism Financing Directive, EBA/REC/2018/02, 11 July 2018

247,248

ECHA Board of Appeal case A-001-2010, 10 November 2011

215, 216

EIOPA, Consultation Paper on the Proposal for Guidelines on Own Risk and Solvency Assessment (2011) EIOPA-CP-11/008

EIOPA, Public Statement on Consultation Practices (2011) EIOPA-BOS-11-016 127

EIOPA, Guidelines on Complaints-Handling by Insurance Undertakings (2012) EIOPABoS-12/069

EMA, Procedure for European Union Guidelines and Related Documents within the Pharmaceutical Legislative Framework (2009) Doc. Ref. EMEA/P/24143/2004 Rev. 1 corr. 
ESA Board of Appeal, Board of Appeal of the European Supervisory Authorities Rules of Procedure (2020) BoA 202001

European Council, Conclusions of the Presidency, Edinburgh (11-12 December 1992)

European Court of Human Rights, Convention for the Protection of Human Rights and Fundamental Freedoms, Rome, 4 November 1950, ETS no. 5

European Ombudsman, 'Decision of the European Ombudsman closing his inquiry into complaint 1363/2012/BEH against the European Banking Authority' (19 February 2013)

$165,167,168$

European Ombudsman, 'Decision of the European Ombudsman closing her inquiry into complaint 1876/2011/(EIS)LP against the European Banking Authority' 1876/2021/ LP (19 December 2003)

European Ombudsman, 'Decision of the European Ombudsman closing her inquiries into complaints 1874/2011/(EIS)LP and 1877/2011/(EIS) LP against the European Insurance and Occupational Pensions Authority' 1874/2011/LP (26 February 2014)

European Ombudsman, 'The composition of ESMA's 30-member Securities and Markets Stakeholders Group' 545/2014/LP (10 October 2016)

European Parliament, Resolution of 21 October 2008 on a strategy for the future settlement of the institutional aspects of Regulatory Agencies (2008) 2008/2103(INI) 12

Final report of the Committee of Wise Men on the regulation of European Securities Markets, 15 February 2001

2,3

Interinstitutional Agreement between the European Parliament, the Council of the European Union and the European Commission on Better Law-Making (2016) OJ L123

$31,51,93,146$

Joint statement and common approach of the European Parliament, the Council of the EU and the European Commission on decentralised agencies (2012) available at accessed 23 February 2021

ReNEUAL, 'ReNEUAL Model Rules on EU Administrative Procedure' (2014) accessed 23 February 2021

Report by The High-Level Group on Financial Supervision in the EU chaired by Jacques de Larosière, 25 February 2009 